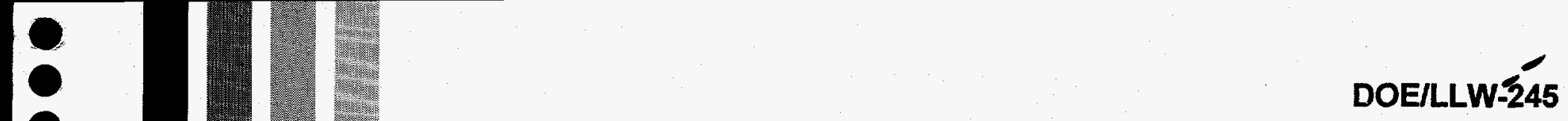

\title{
The Basics in Transportation of Low-Level Radioactive Waste
}

\author{
RECEIVED \\ SEP 141998 \\ OSTI
}

National Low-Level Waste

Management Program
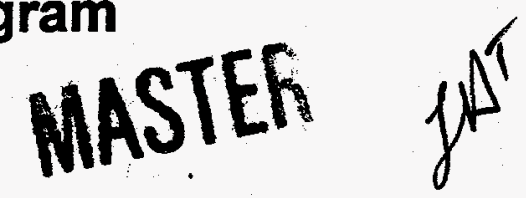

June 1998

DATRIBUTON OF ThIS DOCUMEN IS LAMTED 


\section{DISCLAIMER}

This report was prepared as an account of work sponsored by an agency of the United States Government. Neither the United States Government nor any agency thereof, nor any of their employees, makes any warranty, express or implied, or assumes any legal liability or responsibility for the accuracy, completeness, or usefulness of any information, apparatus, product, or process disclosed, or represents that its use would not infringe privately owned rights. Reference herein to any specific commercial product, process, or service by trade name, trademark, manufacturer, or otherwise does not necessarily constitute or imply its endorsement, recommendation, or favoring by the United States Government or any agency thereof. The views and opinions of authors expressed herein do not necessarily state or reflect those of the United States Government or any agency thereof. 


\section{DISCLAIMER}

Portions of this document may be illegible in electronic image products. Images are produced from the best available original document. 


\title{
The Basics in Transportation of Low-Level Radioactive Waste
}

William E. Allred

Published June 1998

\author{
Prepared for the \\ U.S. Department of Energy \\ Assistant Secretary for Environmental Management \\ Under DOE Idaho Operations Office \\ Contract DE-AC07-761D01570
}




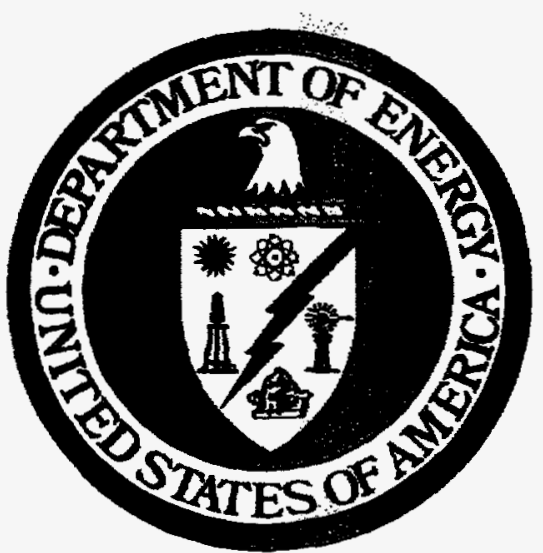

DOE/LLW-245

\section{The Basics in Transportation of Low-Level Radioactive Waste}

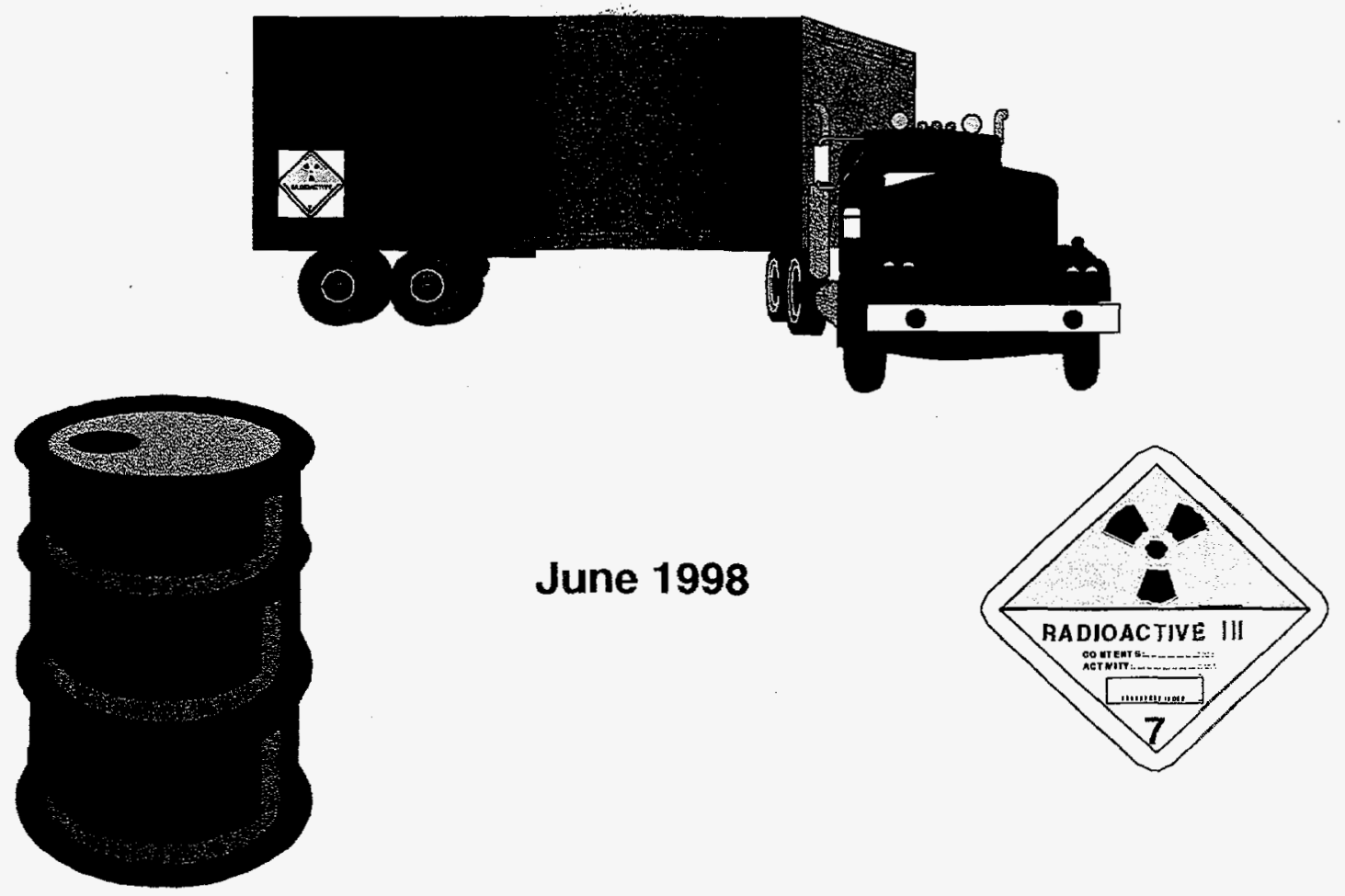

[This document provides basic information on transportation issues involving low-level radioactive waste only and must not be used to determine compliance with the required regulations.] 


\begin{abstract}
This bulletin gives a basic understanding about issues and safety standards that are built into the transportation system for radioactive material and waste in the United States. An excellent safety record has been established for the transport of commercial low-level radioactive waste, or for that matter, all radioactive materials. This excellent safety record is primarily because of people adhering to strict regulations governing the transportation of radioactive materials. This bulletin discusses the regulatory framework as well as the regulations that set the standards for packaging, hazard communications (communicating the potential hazard to workers and the public), training, inspections, routing, and emergency response. The excellent safety record is discussed in the last section of the bulletin.
\end{abstract}


:

0

0

0

0

0

0

0

0

0

0

0

0

0

0

0

,

0

0

0

.

0

0

0
0
0
0
0
0
0
0
0
0
0
0 


\section{ACKNOWLEDGMENTS}

This bulletin is the result of efforts from several individuals. Key contributors from Lockheed Martin Idaho Technologies Company (LMITCO) include Bill Allred of the National Low-Level Waste Management Program (NLLWMP), author of the bulletin, and . other NLLWMP staff for support and reviews. Special mention goes to Gaila Allen of LMITCO for doing an excellent job in developing graphics for the bulletin. A special thanks goes to external reviewers including Rich Gallego of Thomas Gray \& Associates, Tom Dias of New World Technology, and James Ogden of the Texas Department of Health. 


\section{SUMMARY}

This bulletin provides a basic understanding about issues and safety standards that are built into the transportation system for radioactive materials and waste in the United States. An excellent safety record, which is discussed in the last section of this bulletin, has been established for the transport of commercial low-level radioactive waste. The primary factor in the excellent safety record is that people adhere to strict regulations that govern the transportation of radioactive materials and waste.

To help you understand the requirements for transport of low-level radioactive waste, this bulletin first gives an overview of the regulatory framework and then reviews a process that shippers use to determine compliance with the strict regulatory standards and conditions. The process involves responding to three questions. They are:

1. What are the characteristics of the material or waste requiring transport?

2. How can the radioactive material or waste be safely packaged?

3. How is the potential hazard of the transported material or waste communicated to workers and the public?

These three questions and the items that provide the required information are summarized below. For each item listed, the basic regulations are cited, as well as the corresponding page number within this bulletin where the item is discussed.

1. What are the characteristics of the material or waste requiring transport?

The first step is to characterize the material or waste requiring transport. This includes identifying radionuclides present to determine the form ("normal" or "special"), and the quantity (level of radioactivity) present in the material or waste. These characteristics determine the proper shipping name, which is the key in answering questions 2 and 3 . The Hazardous Materials Table, located in Title 49 of the Code of Federal Regulations, Part 172, Section 101 (49 CFR 172.101) lists these requirements for each proper shipping name.

The following items determine the characteristics.

ITEM

Identify Radionuclides

Determine if Regulation Required

Identify Normal Form vs Special Form

Identify Quantity (Activity)

Determine if material or waste is:

Limited or Excepted Quantity

Type A Quantity

Type B Quantity

Highway Route Controlled Quantity

(HRCQ)

Low Specific Activity (LSA)

Surface Contaminated Objects (SCO)

\begin{tabular}{cc} 
CITED & PAGE NUMBER \\
REGULATION & IN BULLETIN \\
\hline
\end{tabular}

49 CFR 173.435

49 CFR 173.403

49 CFR 173.403

49 CFR 173

4

4

5

5

49 CFR 173.403,421-424 6

49 CFR 173.403,431 6

49 CFR 173.403,431 6

49 CFR 173.403. 6

49 CFR 173.403,425 7

49 CFR 173.403 
2. How can the radioactive material or waste be safely packaged?

By knowing the characteristics of the material or waste (information gained from question 1 above), the required packaging can be determined, including radiation and contamination limit requirements during transport. The key to the required packaging is knowing what quantity (activity) category that the material or waste falls under and how the package must perform in routine and accident environments during transport.

The following item: determine packaging requirements and radiation and contamination limits.

\section{ITEM}

Excepted Packages

Industrial Packages

Type A Packages

Type B Packages

Radiation Limits

Contamination Limits

\section{CITED REGULATION \\ PAGE NUMBER IN BULLETIN}

49 CFR $173.403,410$

49 CFR $173.403,410$,

49 CFR $173.403,412,415$

49 CFR $173.403,413,416$

10 CFR 71

49 CFR 173.441

49 CFR 173.443
8

8

8

8

3. How is the potential hazard of the transported material or waste communicated to workers and the public?

These regulations are found in 49 CFR 172 and set the requirements for communicating the potential material transport hazards to emergency responders, shippers, receivers, and the public. Of primary importance is clearly communicating with emergency first responders who must act immediately and notify emergency response organizations for assistance and recovery.

The following items determine the communication requirements.

\section{ITEM}

Proper Shipping Name

Shipping Papers

Package Marking

Package Labeling

Vehicle Placarding

Advance Notificaticn/Routing

Emergency Response information

Training Requirements

Driver's Requirements

\section{CITED PAGE NUMBER REGULATION IN BULLETIN}

49 CFR 172.101 14

49 CFR 172.200

49 CFR 172.300

49 CFR 172.400

49 CFR 172.500

10 CFR 71.97

49 CFR 172.600

49 CFR 172.700

49 CFR 383, 391-397 


\section{CONTENTS}

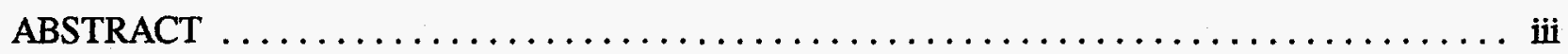

ACKNOWLEDGMENTS $\ldots \ldots \ldots \ldots \ldots \ldots \ldots \ldots \ldots \ldots \ldots \ldots \ldots \ldots \ldots \ldots \ldots$

SUMMARY $\ldots \ldots \ldots \ldots \ldots \ldots \ldots \ldots \ldots \ldots \ldots \ldots \ldots \ldots \ldots \ldots \ldots \ldots \ldots \ldots \ldots \ldots \ldots \ldots \ldots$

INTRODUCTION $\ldots \ldots \ldots \ldots \ldots \ldots \ldots \ldots \ldots \ldots \ldots \ldots \ldots \ldots \ldots \ldots \ldots \ldots \ldots \ldots$

Background $\ldots \ldots \ldots \ldots \ldots \ldots \ldots \ldots \ldots \ldots \ldots \ldots \ldots \ldots \ldots \ldots \ldots$

PRINCIPLES AND LAWS GOVERNING TRANSPORTATION OF LOW-LEVEL RADIOACTIVE

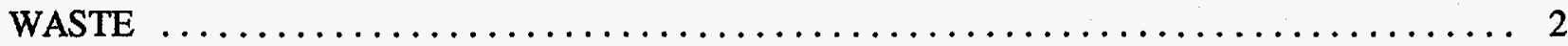

Regulatory Framework $\ldots \ldots \ldots \ldots \ldots \ldots \ldots \ldots \ldots \ldots \ldots \ldots \ldots \ldots \ldots \ldots \ldots \ldots$

How Regulations Work so that Workers, the Public, and the Environment are Safe during Transport of Low-Level Radioactive Waste $\ldots \ldots \ldots \ldots \ldots \ldots \ldots \ldots$

1. What are the Characteristics of the Radioactive Material or Waste requiring Transport? ................................... 4

2. How can the Radioactive Material or Waste be Safely Packaged? . . . . . . 7

3. How is the Potential Hazard of the Material or Waste being Transported

Communicated to Workers and to the Public? .................. 13

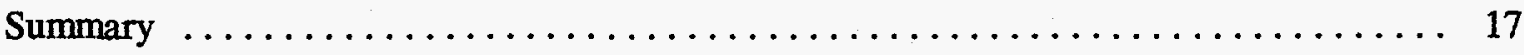

SAFETY IN THE TRANSPORTATION OF LOW-LEVEL RADIOACTIVE WASTE $\ldots \ldots \ldots \quad 17$

Transportation Accidents Involving Commercial Low-Level Radioactive Waste $\ldots \ldots \ldots \ldots$. 18

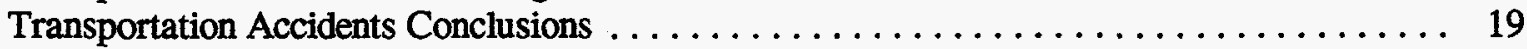




\section{FIGURES}

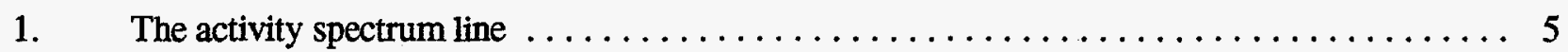

2. Quantity (activity) categories illustrated in the spectrum line $\ldots \ldots \ldots \ldots \ldots$

3. In addition to applicable general packaging/design requirements, Type A packaging must withstand four tests simulating conditions of normal transport, including water spray (rain), drop, compression, and penetration tests

4. Type B packaging must withstand Type A tests and four more tests simulating severe accident conditions including impact, puncture, heat, and water immersion $\ldots \ldots \ldots \ldots \ldots \ldots \ldots$

5. Activity spectrum line as illustrated in Figure 2 with quantity categories, but now adds the packaging categories in the appropriate portion of the spectrum $\ldots \ldots \ldots \ldots \ldots \ldots$

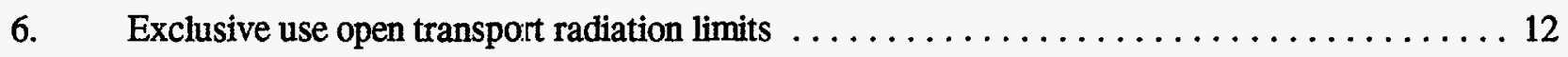

7. Exclusive use closed transport radiation limits $\ldots \ldots \ldots \ldots \ldots \ldots \ldots \ldots \ldots \ldots \ldots$

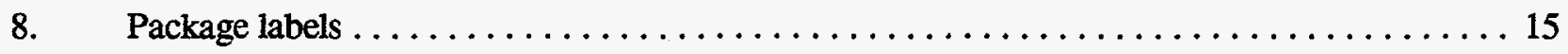

9. A comparison of all shipments of all commodities per year to the number of hazardous and radioactive materials shipments per year $\ldots \ldots \ldots \ldots \ldots \ldots \ldots \ldots \ldots \ldots \ldots \ldots$

\section{TABLES}

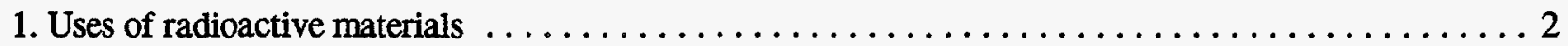

2. Table 11 of 49 CFR 173.443 , noin-fixed external radioactive contamination-wipe limits. . . . . . 13

3. Transportation Accidents involving commercial low-level radioactive waste, 1971-1996 . . . . . 20 


\section{The Basics in Transportation of Low-Level Radioactive Waste}

\section{INTRODUCTION}

The use of radioactive materials in today's society means that the materials and wastes generated from their use will require transportation in commerce at some point during their life-cycle. Although most commercial low-level radioactive waste contains small amounts of radioactivity and poses little transportation risk, people are concerned about transport of all types of radioactive materials through or near their communities. Their concerns often stem from a basic fear of radiation, awareness of the possibility of accidents, and a limited understanding of the physical protection provided for such materials during transport.

This bulletin was prepared to convey information, provide discussion, and give a basic understanding about issues and safety standards that are built into the transportation system for radioactive materials and waste shipments in the United States.

An excellent safety record has been established for the transport of commercial low-level radioactive waste, or for that matter, any radioactive material. The small number of incidents involving radioactivity is demonstrated by a study conducted by the International Atomic Energy Agency. ${ }^{1}$ It stated, "Reviews of the available historical data have shown that there has never been a serious incident involving the dispersal of radioactive material." As of 1997, the Radioactive Materials Incident Report (RMIR) database developed at the Transportation Technology Center of Sandia National Laboratories supports this statement. This database is discussed in the last section of this bulletin.

Safety is built into the transportation system for radioactive material and waste shipments to protect the public, transportation workers, and the environment. The primary factor for this system's excellent safety record has been adherence to regulations that govern the transportation of these materials or waste.

\section{Background}

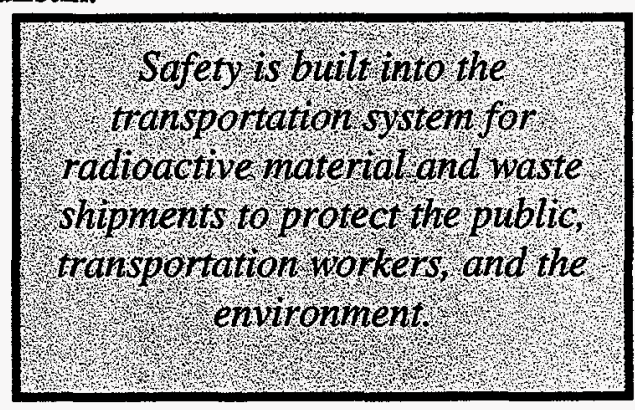

Radioactive materials are used extensively in modern society for generating electric power, research, manufacturing, and a wide range of industrial processes. They are often indispensable for medical diagnosis or therapy. (See examples in Table 1.)

Low-level radioactive waste is the byproduct of many of these very beneficial activities. In fact, it is impossible to entirely eliminate the production of low-level radioactive waste and still maintain our current standard of living. Examples of low-level radioactive waste generated from various processes include protective clothing worn by people who work with radioactive materials, certain worn-out equipment from nuclear power plants, test tubes and vials from hospitals and laboratories, rags, filter papers, plastic, solvents, used filter resins and residues, and consumer products containing low levels of radioactivity such as fire exit signs and smoke detectors.

\footnotetext{
${ }^{1}$ International Atomic Energy Agency (IAEA)-TECDOC-398, Vienna 1986.
} 


\begin{tabular}{|c|c|c|c|}
\hline Radionuclide & Examples of Use & Form Shipped In & $\begin{array}{l}\text { Transport Mode } \\
\text { Used }\end{array}$ \\
\hline Americium 241 & $\begin{array}{l}\text { Industry - help determine where oil wells should be drilled; used in home smoke detectors; } \\
\text { measures lead in dried paint; used in steel and paper production to ensure uniformity }\end{array}$ & $\begin{array}{l}\text { Powder (enclosed } \\
\text { in capsule) }\end{array}$ & \\
\hline Californium 252 & $\begin{array}{l}\text { Medicine - used in cancer research and treatment (particularly cervical, ovarian, and brain } \\
\text { cancers) } \\
\text { Industry - used to detect explosives in luggage at airports; measures moisture in soil at } \\
\text { construction sites and moisture in materials stored in silos; serves as a nuclear reactor startup } \\
\text { source }\end{array}$ & Solid & \\
\hline Cobalt 60 & $\begin{array}{l}\text { Medicine - treats cancer and suppresses immune reaction in transplants; sterilizes surgical } \\
\text { instruments } \\
\text { Industry - tests welds and casting; checks for internal structural flaws; locates buried ntility } \\
\text { conduits } \\
\text { Agriculture - preserves poultry, fru.ts, and spices }\end{array}$ & Solid & \\
\hline Iodine 131 & $\begin{array}{l}\text { Medicine - used to diagnose and tre at medical disorders and as a tracer in medical observation, } \\
\text { such as determining thyroid irregularities }\end{array}$ & Liquid & \\
\hline Iridium 192 & $\begin{array}{l}\text { Medicine - used in treatment of proitate cancer } \\
\text { Industry - used to check the integrity of pipeline welds, boilers, and aircraft parts }\end{array}$ & Solid & \\
\hline Plutonium 238 & Medicine - powers pacemakers and has powered NASA spacecraft & $\begin{array}{l}\text { Solid } \\
\text { (enclosed in } \\
\text { capsule) }\end{array}$ & \\
\hline $\begin{array}{l}\text { Hydrogen3 } \\
\text { (Tritium) }\end{array}$ & $\begin{array}{l}\text { Industry - illuminates paint when rixed with zinc sulfide; traces water flows; used in self- } \\
\text { luminous aircraft and commercial exit signs; used as molecular label in studies of metabolism, } \\
\text { biosynthetics, and cytology }\end{array}$ & Solid & \\
\hline
\end{tabular}

Table 1. Uses of radioactive materials

\section{PRINCIPLES AND LAW/S GOVERNING TRANSPORTATION OF LOW-LEVEL RADIOACTIVE WASTE}

Protecting the public against radiation during transportation is based on the philosophy that if accidents occur, adequate protection will be provided. This protection is provided because people who handle and transport these materials adhere to strict regulations that govern the transportation of radioactive materials. These regulations provide standards for packaging (the degree of protection based on the level and type of radioactivity contained), hazard communications (which identifies potential hazard being transported), training, inspections, routing, and emergency response.

\section{Regulatory Framework}

The International Atomic Enes:gy Agency (IAEA), an agency of the United Nations, issues safety standards for radiation protection based on more than 50 years of research and experience with radioactivity. Recommendations for these standards come from different agencies including the International Commission on Radiation Protection (ICRP) and the National Council on Radiation Protection and Measurements (NCRPM). These organizations are composed of physicians, radiologists, and scientists

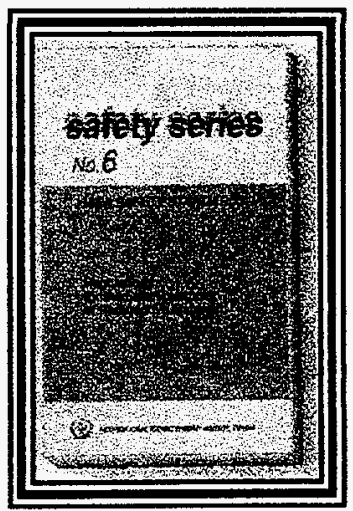


specializing in the biological effects of radiation. These standards are adopted by most countries, including the United States. For transportation, the IAEA issues and updates a safety series document entitled Regulations for the Safe Transport of Radioactive Materials. The United States has adopted standards from this document as its basis for regulating the transport of radioactive materials.

In the United States, Federal regulations that govern the transportation of low-level radioactive waste are issued and administered primarily by two agencies ${ }^{2}$, the U.S. Department of Transportation (DOT) and the U.S. Nuclear Regulatory Commission (NRC). The roles of the DOT and the NRC are described in a memorandum of understanding (MOU) between the two agencies for developing and implementing consistent and comprehensive regulations and requirements for the safe transportation of radioactive materials, and to avoid duplication of effort. The DOT is responsible for regulating the safe transportation of all hazardous materials, including radioactive materials. For example, the DOT sets standards for communicating potential hazards to the public (hazard communications), package design standards for shipments of lower-activity radioactive materials, radiation protection programs, training of shippers, and vehicle safety and maintenance. The NRC sets package and containment standards for higher-activity radioactive materials, investigates accidents/incidents, and regulates radiation protection programs of NRC licensees. The NRC also acts as a technical advisor to the DOT. In the case of lowlevel radioactive waste, the NRC sets requirements for waste classification, waste form, and manifest specifications for adherence to transportation requirements.

DOT uses an "audit program" to ensure compliance with regulations for the safe transportation of radioactive materials or waste. Companies transporting such material or waste are assigned a safety rating based on inspection results, safety record, and the size and number of vehicles. On the basis of the safety rating, the DOT prioritizes its audits of transportation companies to ensure compliance with the regulations specified in the Code of Federal Regulations.

In addition to Federal regulations, states also have standards and safeguards in place to ensure transportation safety. In the event of a transportation accident, emergency response teams of trained personnel are formed from various organizations including the local fire, police, and highway departments; local and state health departments; and state radiation agencies. These personnel are typically trained to respond to various types of accidents, including transportation accidents involving radioactive materials.

\section{How Regulations Work so that Workers, the Public, and the Environment are Safe during Transport of Low-Level Radioactive Waste}

What are the regulations, and how are they administered so that people and the environment are safe from radioactive materials while they are in transport?

${ }^{2}$ DOT and NRC regulations are found in the Code of Federal Regulations (CFR), which is an annuallyrevised codification of the general and specific rules subject to Federal regulation. The CFR is divided into Titles representing broad areas subject to Federal regulation, and titles are further subdivided into Parts, Sections, and Paragraphs for specific topics. DOT regulations are found under Title 49 and NRC regulations are found under Title 10. For example, if you wanted to find the DOT regulation 49 CFR 172.101, the Hazardous Materials Table, you would first go to Title 49 in the Code of Federal Regulations (CFR), then go to Part 172 and Section 101. The Part and Section are listed on the top of every page just like using a dictionary. 
This can be answered by responding to three questions (see sidebar). They form a sequence of steps that a shipper can take to meet the strict regulatory standards and conditions that govern the transport of radioactive materials.

1. What are the characteristics of the malerial or waste requiring transport? The first step is to determine characteristics of material, which then determines the proper shipping description, the proper shipping name, ID number radionuclides present, form of material, and activity (quantity).

2. How can the radioactive material or waste be safely packaged for transport? The proper shipping name determines the correct packaging requirements and the allowable radiation and contamination limits during transport.

3. How is the potential hazard of the transported radioactive material or waste communicated to workers and the public? After determining the material charscteristics and appropriate transport packaging, the potential radiation hazards can be communicated to the workers and the public (marking, labeling, placarding, etc.)

These questions are explained in more detail below.

\section{What are the Characteristics of the Radioactive Material or Waste requiring Transport?}

This answer is derived by determining the following:

Radionuclides being transported. Identify the radionuclides in the materials being shipped. DOT regulation 49 CFR 173.435 contains a table that lists almost 400 specific radionuclides with activity values, to be used as package limit requirements ${ }^{3}$, given for each radionuclide.

Radioactive materials or waste that require regulation. Not all radioactive material requires regulation during transport. Radioactive materials that require regulation during transport are defined as those materials that spontaneously emit ionizing radiation and have a specific activity (activity per gram) equal to or larger than 0.002 microcuries per gram ( 70 becquerel per gram). The unit of measurement for radioactivity is known as either the curie or becquerel. The U.S. unit of activity is the curie (Ci) which equals 37 billion disintegrations or emissions per second $(\mathrm{d} / \mathrm{s})$. The becquerel $(\mathrm{Bq})$ is an international unit (SI) of activity that equals 1 disintegration (emission) per second $(\mathrm{d} / \mathrm{s})$. This demarcation of the activity per gram allows a distinction between rnaterials of extremely low radioactivity and therefore "exempt" from regulation, and those that are regulated as radioactive material for purposes of transportation. Materials that do NOT meet this definilion are not subject to the radioactive material provisions of the

3 These package activity limit requirements listed in the regulations for each radionuclide come from recommendations given by the International Atomic Energy Agency (IAEA). The activity limit values are derived from actual experience with exposure (occupational and accidental) and dosimetric models whereas the limiting values results from certain worst case scerarios. The IAEA activity limit value for a Type A package, a standardized type of packaging, is known as a "reasonable safe limit." That is, if an accident occurred and radioactivity were released from this packige, the release would be at such a low activity, that it would be very unlikely that exposure from this release would cause any related injury or health problems.

${ }^{4}$ Note: Do not mistake Exempt for Excepted, which is also used in this document. In this document the following definitions apply. Exempt is defined as radioactive material that is not regulated (exempted) for transport purposes (is not in excess of $70 \mathrm{Jg} / \mathrm{gm}$ ). Excepted is defined as radioactive material that is regulated, but is omitted (excepted) from some of the transportation regulation requirements. 
DOT regulations. A word of caution, however: some radioactive materials that are exempt from regulation during transport may not be exempt from the licensing requirements or other regulations from the NRC, Environmental Protection Agency (EPA), or Agreement States. Agreement States are States that accept authority, under NRC guidelines, to regulate radioactive materials.

The "form" of the material or waste. There are two forms for radioactive material in shipment. These forms are known as "special" or "normal." "Special-form" is usually an encapsulated source (sealed within a container) of very high physical integrity or a piece of solid metallic material. Essentially, with special-form material, the container (capsule) must be destroyed in order to get to the radioactive contents. If a container can be normally opened easily, the contents is not special-form radioactive material. Federal regulations ( 49 CFR 173.469) prescribe the physical testing required by the shipper before certifying that the material is in fact "special-form." Because special-form material is completely sealed within its container, release is minimized (essentially non-dispersible), even in a severe accident. "Normal-form" is radioactive material that has NOT been demonstrated to qualify as "special-form" material. Therefore, normal-form radioactive material is inherently more dispersible than special-form material. Most low-level radioactive waste is normal-form.

The "quantity" of radioactivity in the material or waste. The primary factor for achieving safety in transporting radioactive materials is the use of proper packaging for the specific radioactive material. Packages have activity limit requirements ("quantity" of radioactivity in the material). As discussed above, radioactive material activity limits for transportation purposes are based on the values given to almost 400 specific radionuclides listed in the DOT regulations. This list is known as the $A_{1} / A_{2}$ table ( 49 CFR 173.435) . Each radionuclide has an $A_{1}$ ("special-form") or $A_{2}$ ("normal-form") value. These two values are simply the maximum activity allowed for that radionuclide that is transported in Type A packaging. This is known as the $A_{1} / A_{2}$ value (See the activity spectrum line in Figure 1.). Packaging is discussed later in this bulletin.

\section{The Activity Spectrum Line}

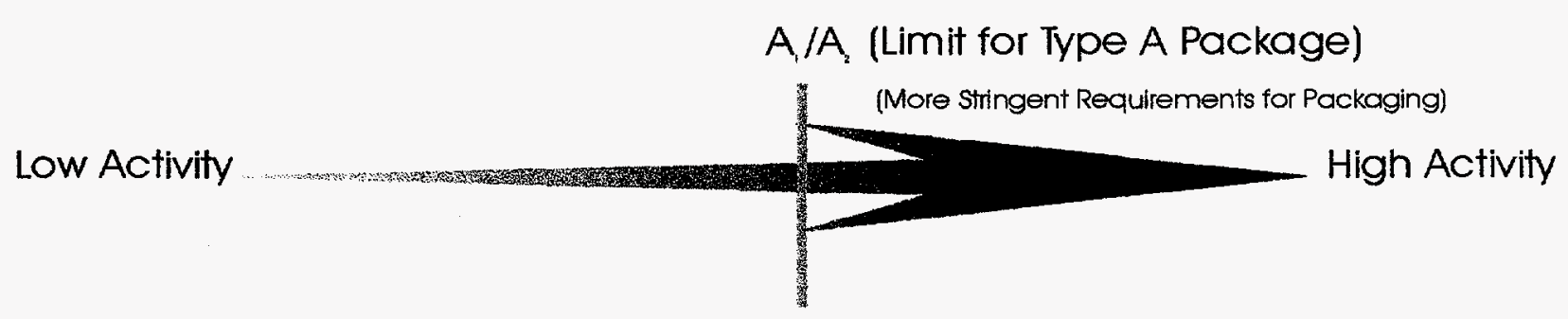

Figure 1. The activity spectrum line. Radioactive material or waste being shipped would fall someplace on the spectrum line (horizontal line) depending on its quantity (level of radioactivity). Lower activity materials or waste would be to the left with the higher activities to the right. The $A_{1} / A_{2}$ value limit (vertical line) is the maximum activity value that can be shipped in a Type $A$ package (Each radionuclide being shipped has its own $A_{1} / A_{2}$ value.). The further to the right on the spectrum line, the more stringent requirements for packaging. 
For radioactive materials transport, there are four main "quantity" (activity) type categories: (1) Limited or Excepted; (2) Type A; (3) 'Type B; and (4) Highway Route Controlled Quantity (HRCQ). In addition, there are two "special categories" known as low-specific activity (LSA) and surface contaminated objects (SCO).

\section{Limited or Excepted quintity}

Limited quantity materials are excepted from many of the regulatory requirements that apply to other categories of waste (Type A and B quantities and above). Regulations state that solid limited quantity materials cannot contain more than $1 / 1,000$ of the $A_{1} / A_{2}$ value $\left(10^{-3}\right)$. Examples of limited or excepted quantities include consumer goods such as smoke detectors and exit signs.

\section{Type A quantity}

If the material exceeds the $A_{1} / A_{2}$ values for limited quantities but does not contain more than Type A quantity values, then the metterial is Type A quantity. Examples of Type A quantities include radiopharmaceuticals and low-level radioactive waste.

\section{Type B quantity}

If the material exceeds the Type A quantity values but contains less than a Highway Route Controlled Quantity, the material is Type B quantity. Examples of Type B quantities include higher activity radionuclides such as used for radiography.

\section{Highway Route Controlled Quantities}

Any material that exceeds Type B quantity values is a Highway Route Controlled Quantity, or HRCQ. HRCQ is a quantity within a single package that exceeds (1) 3,000 times the $A_{1} / A_{2}$ value or (2) is 27,000 curies or $1000 \mathrm{Tbq}\left(\mathrm{T}=\mathrm{tera}\right.$, which is $\left.10^{12}\right)$, whichever is least. Packages containing a HRCQ of radioactive material are subject to specific requirements that include using preferred routes, filing detailes reports, and taking specified training. Examples of HRCQ include spent nuclear fuel and high-level radioactive waste.

The application of the $A_{1} / A_{2}$ values to define these four quantity categories is illustrated in the activity spectrum line (Figure 2.). This is the same spectrum line used in Figure 1 with the addition of the quantity categories. This spectrum line starts with the definition of material or waste that needs to be regulated during transport (lower activities on the left) with increasing quantity (activity) indicated towards the right. The further to the right, the rnore rigorous the safety requirements and control.
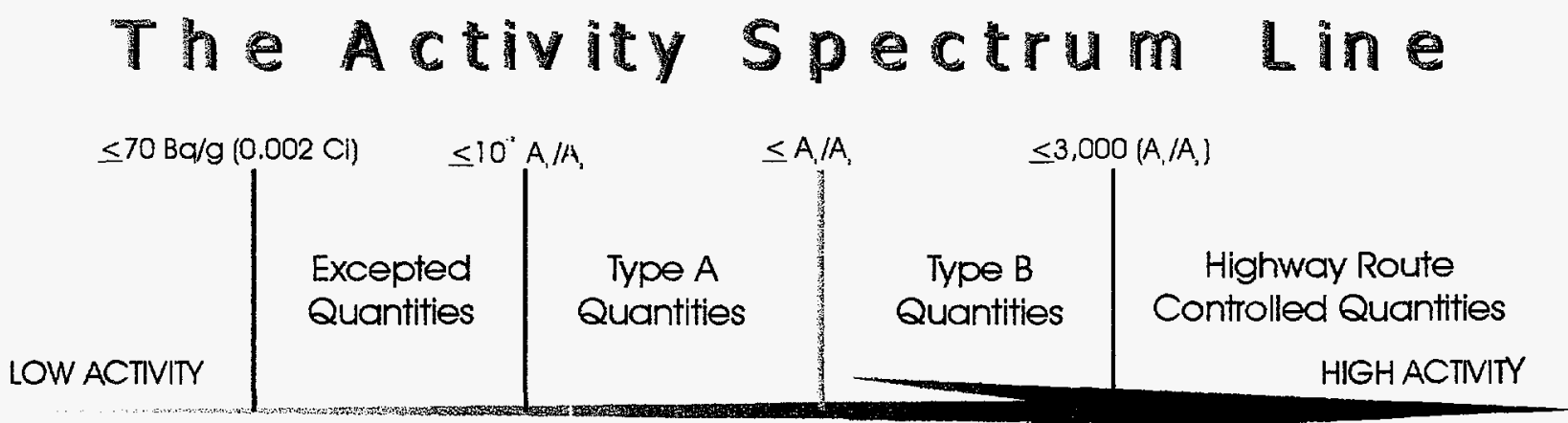

Figure 2. Quantity (activity) categories illustrated in the spectrum line. 
Two other "special categories" used in radioactive materials transport are low-specific activity (LSA) and surface-contaminated object (SCO) material. These categories are not based on maximum activity allowed for each quantity category, such as above, but are based on specific activity (Ci or Bq/gm) or surface contamination ( $\mathrm{Ci}$ or $\left.\mathrm{Bq} / \mathrm{cm}^{2}\right)$. LSA and SCO materials present a relatively low hazard during transportation because of their limited concentration and uniform distribution. LSA and SCO categories are extremely important to shipments of low-level radioactive waste. These categories offer relief from certain packaging and transportation requirements, which translates into large cost savings.

\section{LSA}

LSA is a concentration (curies or Bq/gm) category of radioactive material. LSA materials are those that present a relatively low hazard as a result of their limited concentration. LSA, depending on type of material and concentration, is grouped into three categories, LSA-I, LSA-II, and LSA-III. An example of LSA waste would be contaminated rocks or soil.

\section{SCO}

$\mathrm{SCO}$ is a contamination ( $\mathrm{Ci}$ or $\mathrm{Bq} / \mathrm{cm}^{2}$ ) category of radioactive material. SCO materials are solid objects that have radioactive contamination on its surfaces. SCO is an important category for shipping materials originating from cleanup, remediation, and decontamination activities. SCO is grouped into two categories, SCO-I and SCO-II, which determines packaging requirements. An example of SCO waste would be used equipment from a nuclear power plant such as a pump.

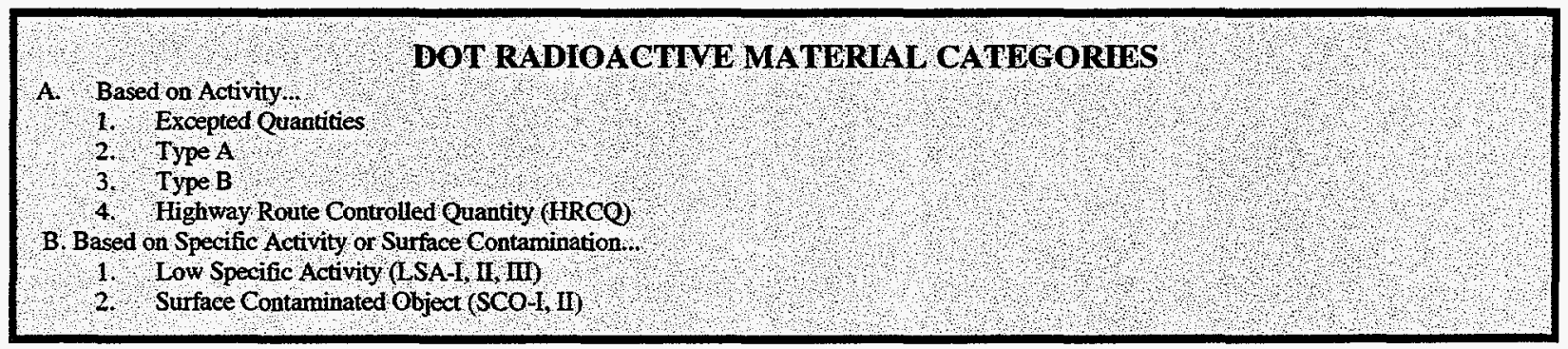

The proper shipping name $\mathrm{e}^{5}$ is determined from information gained in question 1 (i.e., radionuclides present, waste form, and quantity (activity) or concentration of the material or waste). The proper shipping name is essential in determining the required transport packaging for a specific material as well as determining radiation and contamination limits and hazard communication requirements.

\section{How can the Radioactive Material or Waste be Safely Packaged?}

Safety in the transport of radioactive materials primarily depends upon proper packaging. The material type, form, and quantity or concentration of the radioactive material and the expectations of how the package has to perform in routine and accident environments during transportation help determine the packaging required for a particular material or waste. "Packaging" refers to the containment system (the box, the barrel, the cask, etc., without the material). "Package" refers to the containment system plus the

${ }^{5}$ The proper shipping name is a key component of the total system for providing safety in transport of radioactive materials or waste. The Hazardous Materials Table in 49 CFR 172.101 lists the proper shipping name together with the requirements for packaging, radiation and contamination limits, shipping papers, marking, labeling and transport vehicle placarding applicable to their shipment. 
material within it (i.e., radioactive waste). The basic radioactive material packaging categories are Excepted "strong tight packaging", Type A, and Type B. Industrial packaging, an international standard for packaging that was recently added to the $49 \mathrm{CFR}$, is prescribed for most shipments of LSA and SCO materials. In addition to packaging, reıdiation and contamination limit requirements must also be discussed. The following subsections discuss packaging and radiation and contamination limits.

\section{Packaging}

\section{- Excepted packaging}

An excepted package is not subject to most of the regulatory requirements applicable to other packages such as Type A and Type B. However, excepted packages must still meet all the general packaging and design requirernents stated in 49 CFR 173.410 . It is considerably easier to prepare and ship excepted packages. Examples of materials transported in excepted packaging include consumers goods such as smoke detectors and exit signs.

\section{- Industrial packaging}

The new category "industrial packaging" (IP), an international standard of packaging, is prescribed for use in most shipments of LSA and SCO materials (49 CFR 173.411). Three categories have been established, IP-1, IP-2, and IP-3. They are listed in order of their ability to contain higher activity materials and to meet the required testing requirements, such as withstanding falls (drop test) and compression (stacking tests). DOT requires that the packaging protect its contents during normal transport conditions.

\section{- Type A packaging}

Type A packaging must be designed to comply with the general packaging and design requirements in 49 CFR 173.411, plus the additional testing requirements for Type A packaging in 49 CFR 173.412. the packaging must prevent the loss or dispersal of its contents and maintain its shielding properties when it is subjected to normal transport conditions. These normal conditions derive from performance tests and er.vironmental conditions intended to simulate normal rigors and physical stresses such as rough handling conditions (see Figure 3). Examples of materials transported in Type A packaging include radiopharmaceuticals and low-level radioactive waste.

\section{- Type B packaging}

Type $\mathrm{B}$ packaging must meet the general packaging and performance standards for Type $\mathrm{A}$ packages stated in 49 CFR 173.412 and additionally must have the ability to survive certain serious accident damage tests (hypothetical accident conditions). This means that under such conditions the contents of the jackage will not be released. The performance criteria for Type B packaging are prescribed in 10 CFR Part 71 of the NRC regulations (see Figure 4). Examples of materials transported in Type B packaging include spent nuclear fuel, high-level radioactive waste, and high concentrations of sorne radionuclides such as cesium and tritium. 


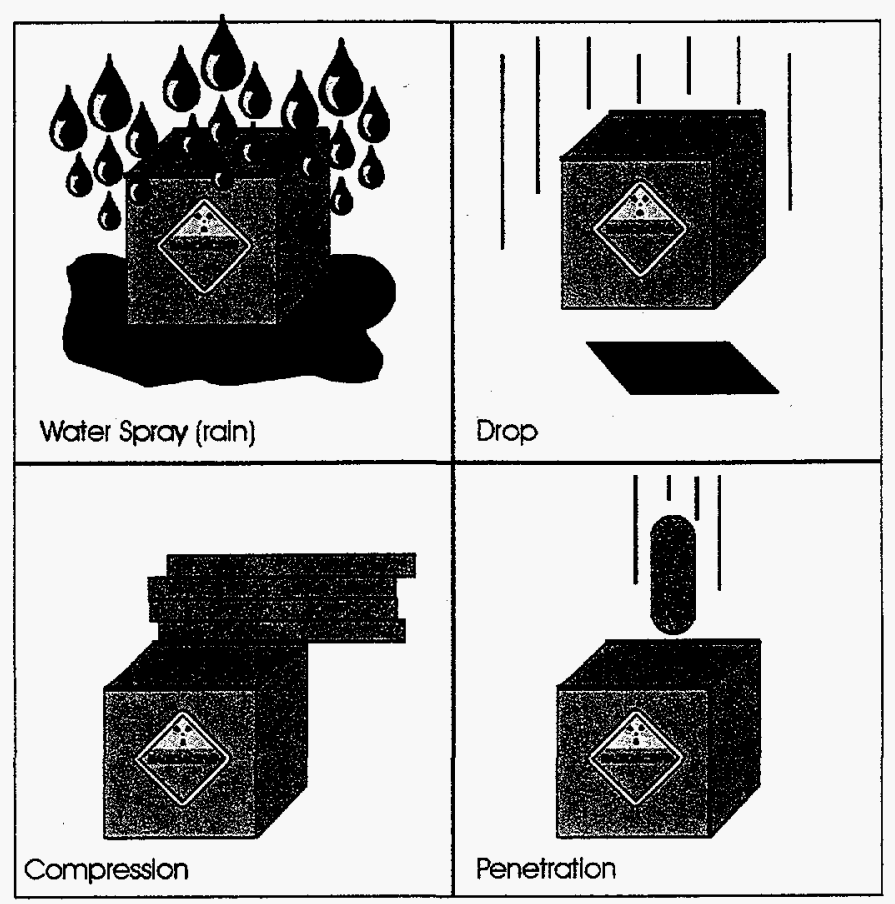

Figure 3. In addition to applicable general packaging/design requirements, Type A packaging must withstand four tests simulating conditions of normal transport, including water spray (rain), drop, compression, and penetration tests.

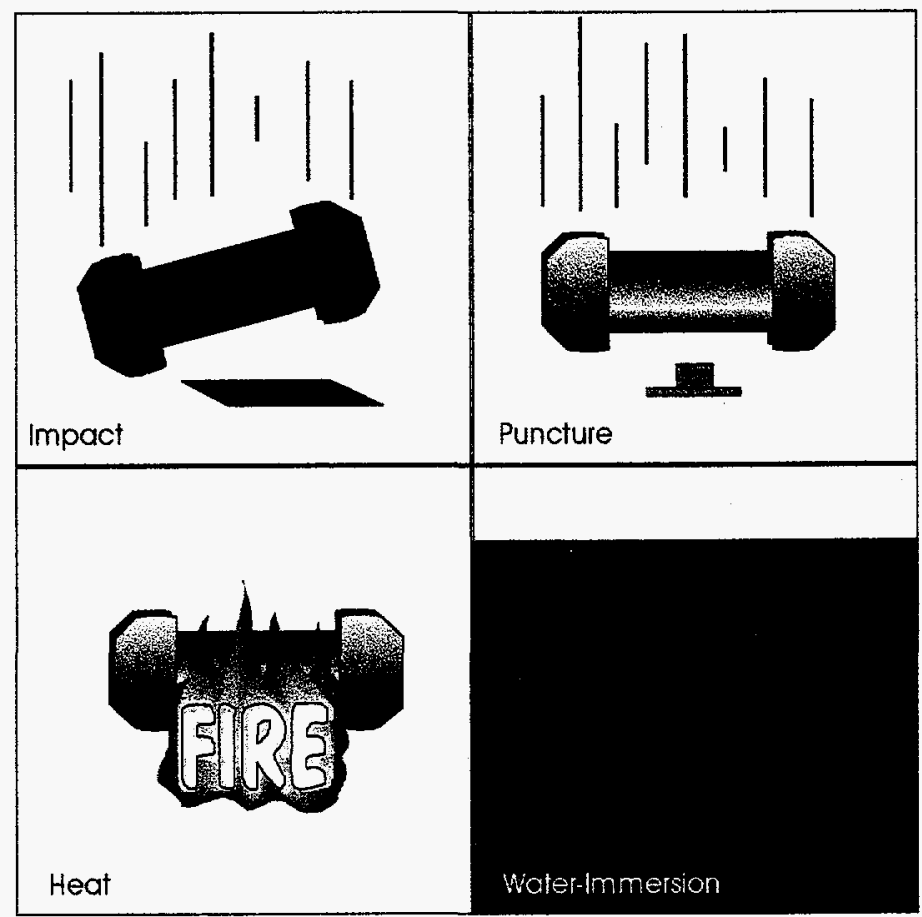

Figure 4. Type B packaging must withstand Type A tests and four more tests simulating severe accident conditions, including impact, puncture, heat, and water immersion. 
Figure 5 repeats the $A_{1} / A_{2}$ activity spectrum line previously illustrated in figures 1 and 2 , but now adds the basic packaging categories in the appropriate portion of the spectrum. Industrial packaging is shown on the figure to give an idea of where it would fit within the spectrum. Depending on category, i.e., IP-1, IP-2, or IP-3, most Industrial parkaging would be dispersed through excepted to lower activity Type A packaging in the spectrum.

\section{The Activity Spectrum Line}

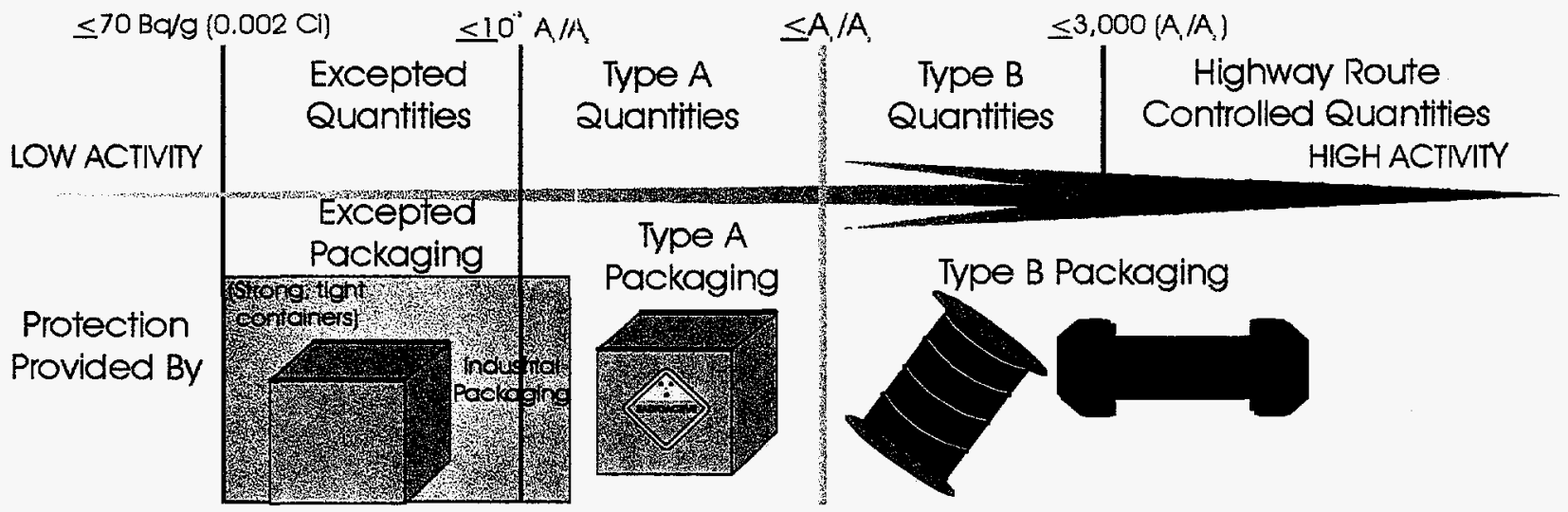

Figure 5. Quantity (activity) spectrum as illustrated in Figure 2, but now adds the basic packaging categories in the appropriate portion of the spectrum.

\section{Radiation and Contamination Lilmits.}

There are also both radiation and contamination limit requirements on packages and vehicles for radioactive material or waste transport. Radiation limits are determined by measuring the activity being emitted at the external surface of the package or vehicle. Contamination limits are determined by measuring the removable (nonfixed) contaminaticn of the external surface area of a package.

The following terms will clarify the discussion of the required radiation and contamination limits for transport of radioactive materials. After defining these terms, radiation and contamination limits will be discussed.

\section{- $\quad$ Rems and sieverts}

The biological effect of radiation is called dose or dosage. Radiation limits are measured in rems (U.S. unit) or sieverts (International unit). Rems or sieverts (Sv) are a unit of radiation dosage. Low radiation levels encountered regularly by human beings are measured by the millirem (mrem), which is $1 / 1,000 \mathrm{rem}$. A sievert is equal to $100 \mathrm{rems}$. For example, in conversion, 200 mrem equals $2 \mathrm{mSv}$ or $1,000 \mathrm{mrem}$ equals $10 \mathrm{mSv}$. These units are usually measured per hour (200 $\mathrm{mrem} / \mathrm{hr}$ or $2 \mathrm{mSv} / \mathrm{hr}$ ). To put these figures into perspective note that the average person in the United States receives $360 \mathrm{mrem}(3.6 \mathrm{mSv}$ ) per year from natural and manmade sources of radiation, most of this from natural background. People living close to a transportation route (less than 100 feet away) of a vehicle containing the highest level or greatest quantity of radioactive materials (spent fuel or high 1e:vel waste) would receive 0.0005 mrem per routine shipment. In 
comparison, people spending a day at the beach would receive around 0.28 mrem of radiation. As another example, if 100 spent fuel shipments pass by every year, these people would only receive an additional 0.05 mrem per year, about half the radiation they receive annually from watching television. ${ }^{6}$

\section{- Exclusive and non-exclusive use shipments}

An exclusive use shipment is a shipment that is entirely under the control of a single consignor (shipper) and a single consignee (recipient). The carrier (transport company) may not disturb the load, off-load any packages en route, transfer the packages to another vehicle, or add additional packages to the load, unless performed by trained personnel under the direct supervision of either the consignee or consignor.

Because rigorous controls are imposed on an exclusive use shipment, these shipments are given relief from certain regulatory requirements that apply to other types of shipments (non-exclusive use shipments). For example, for LSA shipments, an exception is given for package labeling, or certain specification packaging requirements.

A non-exclusive use shipment is the opposite of an exclusive use shipment. The shipment is not under the control of a single consignor (shipper) or consignee (recipient). The carrier (transport company) may disturb the load, off-load any packages en route, transfer the packages to another vehicle, or add additional packages to the load. An example would be United Parcel Service.

\section{- Closed or open vehicles}

A closed transport vehicle is equipped with a securely-attached exterior enclosure that during normal transportation restricts the access of unauthorized persons to the cargo space containing the radioactive materials. The enclosure may be either temporary or permanent, and must limit access from top, sides, and ends.

An open transport vehicle does not have an enclosure and does not restrict access of unauthorized persons to the cargo space. An example would be a flat-bed trailer.

\section{- Transport Index}

The Transport Index (TI) is a dimensionless number (rounded up to the next tenth) placed on the label of a package to designate the degree of control to be exercised by the carrier during transportation. TI is determined as follows:

Measure the maximum radiation level in mrems per hour at one meter ( 3.3 feet) from the external surface of the package, then round up to the next tenth. For example, at one meter $5.43 \mathrm{mrem} / \mathrm{hour}$ would have a TI of 5.43 ; rounded up $=5.5$.

The Transport Index is the key parameter used by the carrier to control stowage of radioactive packages in non-exclusive use vehicles.

\footnotetext{
6"Transporting Radioactive Materials," DOE/EM-0097, April 1993
} 


\section{- Radiation limits}

The limits on radiation levels of a specified package offered for transportation are listed in 49 CFR 173.441. The package shall be designed and prepared for shipment so that under conditions normally incident to transportation, the radiation level does not exceed $200 \mathrm{mrem} / \mathrm{hour}$ ( 2 $\mathrm{mSv} /$ hour) at any point on the external package surface and the Transport Index does not exceed 10.

Package radiation limits for packages in open or closed non-exclusive use conveyances are the same as stated above. Vehicle requirements in all open or closed non-exclusive use conveyances stipulate that the TI of all radioactive packages in the vehicle cannot total more than 50 per 49 CFR 173.

For open exclusive use shipments, the package limits stated above are applicable. In a closed exclusive use vehicle, the radiation level at any point on the external surface of the package can be $\leq 1,000 \mathrm{mrem} / \mathrm{hour}(10 \mathrm{mSv} /$ hour$)$. These values and other requirements are shown in Figures 6 and 7.

\section{- Contamination limits}

Limits for removable (nonfixed) radioactive contamination on the external surface of a package offered for transportation are prescribed in 49 CFR 173.443. The level must be kept As Low As Reasonably Achievable (ALARA) and must not exceed the limits set forth in Table 11 of 49 CFR 173.443 (see Table 11 restated below as Table 2). The contamination limits of Table 11 generally apply to all radioactive materials packages when transported as non-exclusive use shipments. For packages shipped as exclusive-use, the provisions of 49 CFR 173.443 apply at the beginning of transport. During transport, the removable (nonfixed) radioactive surface contamination may not exceed 10 times the regular limits.

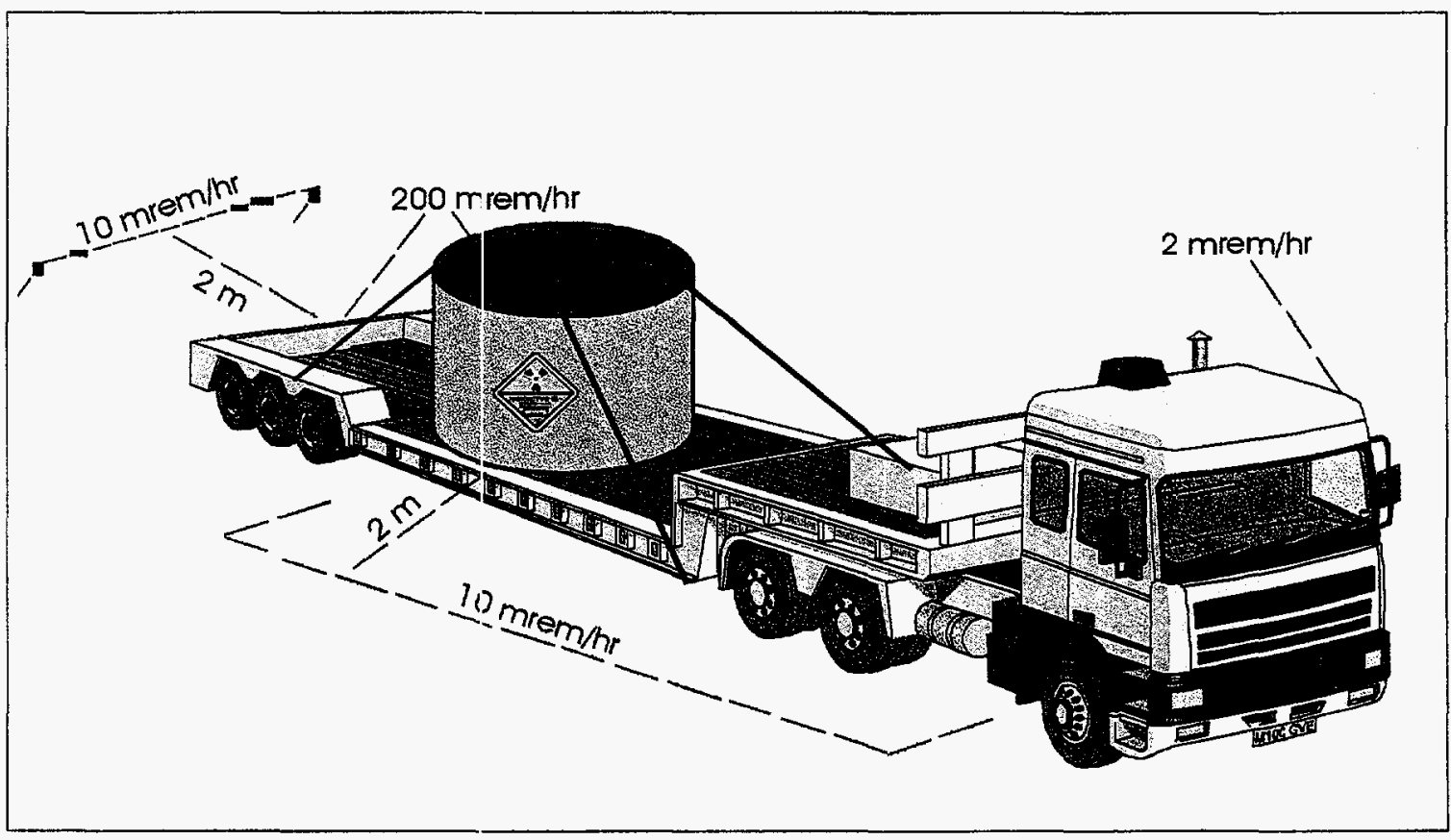

Figure 6. Exclusive use open transport radiation limits. 


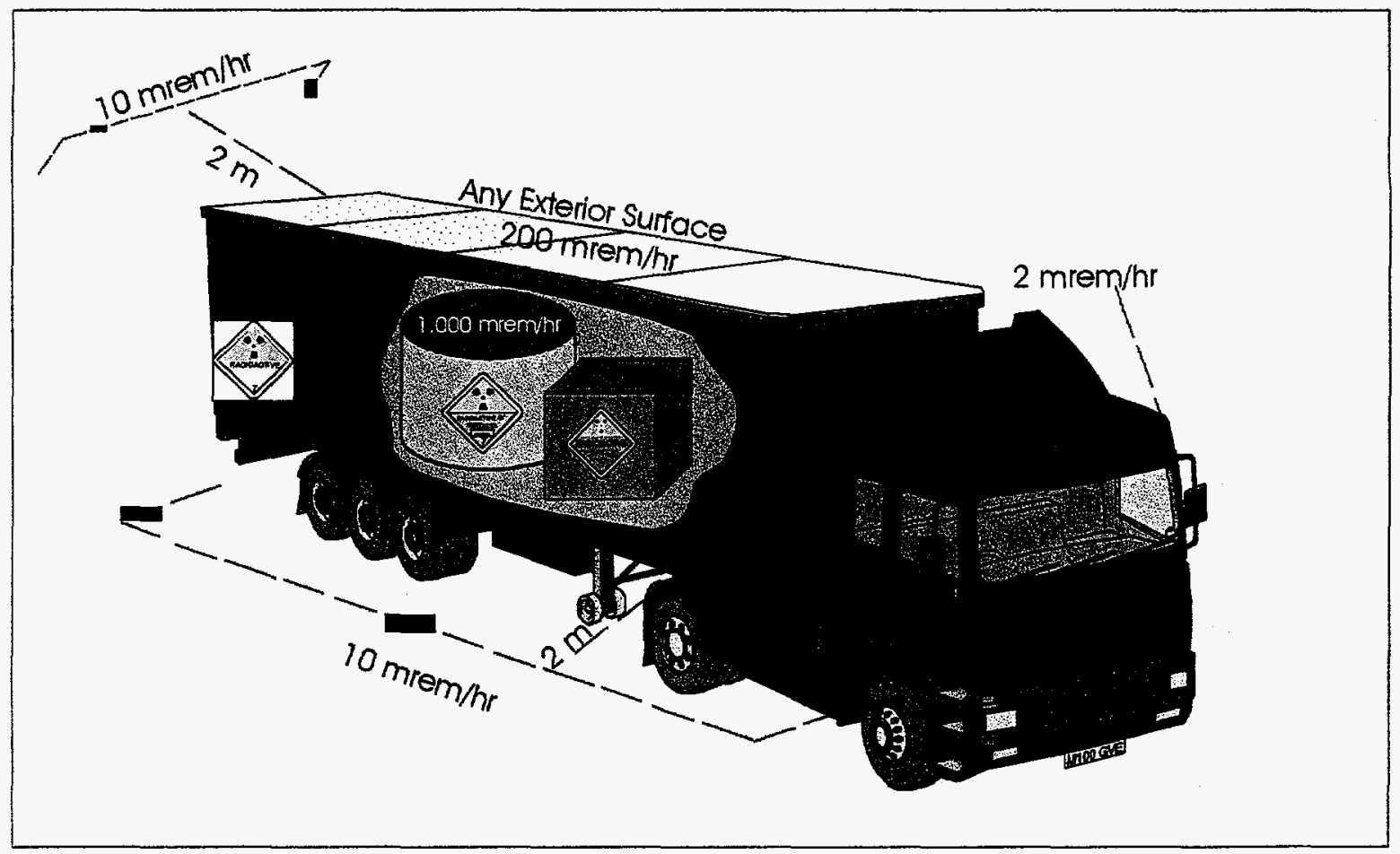

Figure 7. Exclusive use closed transport radiation limits.

\begin{tabular}{|l|c|c|c|}
\hline \multirow{2}{*}{ Contaminant } & \multicolumn{2}{|c|}{ Maximum Permissible Limits } \\
\cline { 2 - 4 } & $\mathrm{Bq} / \mathrm{cm}^{2}$ & $\mathrm{uCi} / \mathrm{cm}^{2}$ & $\mathrm{dpm} / \mathrm{cm}^{2}$ \\
\hline $\begin{array}{l}\text { Beta and gamma emitters and } \\
\text { low toxicity alpha emitters }\end{array}$ & 0.4 & $10^{-5}$ & 22 \\
\hline $\begin{array}{l}\text { All other alpha emitting } \\
\text { radionuclides }\end{array}$ & 0.04 & $10^{-6}$ & 2.2 \\
\hline
\end{tabular}

$\mathrm{cm}=$ centimeters

$\mathrm{C} \mathbf{i}=$ microcuries

$\mathrm{dpm}=$ disintegrations per minute

Table 2. Table 11 of 49 CFR 173.443, non-fixed external radioactive contamination-wipe limits.

\section{How is the Potential Hazard of the Material or Waste being Transported Communicated to Workers and to the Public?}

The requirements for communicating the potential hazards of the material being transported to emergency responders, shippers, receivers, and the public are found in 49 CFR 172. Of primary importance is clearly communicating with the emergency first responder. In case of an incident, a first responder must immediately know what the hazard is in order to take appropriate emergency actions and contact response organizations for assistance and recovery.

These requirements cover proper shipping name and classification, shipping papers, package marking, package labeling, transport vehicle placarding, advance notification/routing, and emergency response information. These are discussed in more detail below. As stated earlier, the Hazardous 
Materials Table, 49 CFR 172.101, identifies these requirements for each proper shipping name.

Proper shipping name. The proper shipping name is the official name that the DOT assigns to a specific hazardous material and must be used on the shipping papers. A four digit number called the "UN number" is assigned to each proper shipping narne for radioactive materials (The letters "UN" are associated with proper shipping names considered appropriate for international transportation as well as domestic transportation.). First responders to transportation emergencies use these UN numbers to determine appropriate protective actions in the DOT Emergency Response Guidebook.

Shipping papers. Certain essential information must be included on shipping papers. A complete and correct shipping paper description for a hazardous material shipment is vital to the carrier, the consignee, and emergency response personnel in the event of an accident. Radioactive waste shipped from generators to processing or disposal facilities require a manifest, which is a shipping document that lists properties of waste container contents.

Basic shipping paper requirements include:

The proper shipping name

The UN hazard class (radioactive materials are hazard class 7)

The UN hazard identification number

The net quantity (activity) of the material

The words RADIOACTIVE MATERIAL, unless these words are in the proper shipping name

The name of the radionuclides

The physical and chemical form

The category of radioactive label

The TI (Transport Index)

The letters " $R Q^{7}$ "

An emergency response telephone number.

Package marking. Packages require information other than the required labels, discussed in the next subsection. This additional information includes (see sidebar):

The proper shipping name

UN hazard identification number

Name and address of consigncr or consignee

Packaging type and certification

"This side up", "this end up"

The letters "RQ" if appropriate

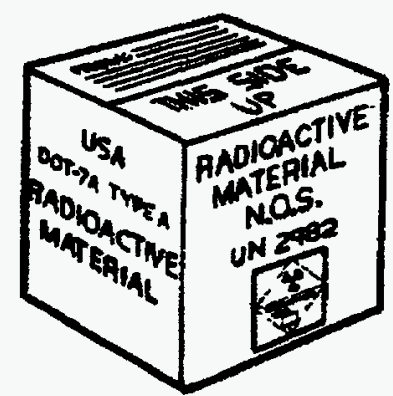

Package labeling. Each package of radioactive materials, unless

excepted, must be labeled on two opposite sides, with a distinctive warning label. Each of the three label categories ("Radioactive White-I," "Radioactive Yellow-II," and "Radioactive Yellow-III") bears a unique trefoil symbol for radioactivity (see Figure 8). The higher the number, the greater the precautions required for safe transport. The label category depends primarily on the radiation levels at the surface of the package and at one meter from the package, expressed as the Transport Index or TI. The radioactive label alerts persons that the package contains radioactive materials and may require special handling and

${ }^{7}$ The letters "RQ," if the shipment is a "hazardous substance," $i . e .$, defined in the regulations as a "Reportable Quantity". See 49 172.101, Appendix A, Table 2 for RQ values of radionuclides. 
stowage distance/separation control. A label with an all-white background indicates that the external radiation level is low and no special stowage controls or handling are required. If the upper half of the label is yellow, the package will have an external radiation level characteristic that requires special handling and control during stowage in transport. If the package bears a yellow label with three red stripes, the transport vehicle must be placarded" Radioactive" by the carrier when the packages are accepted from the shipper.
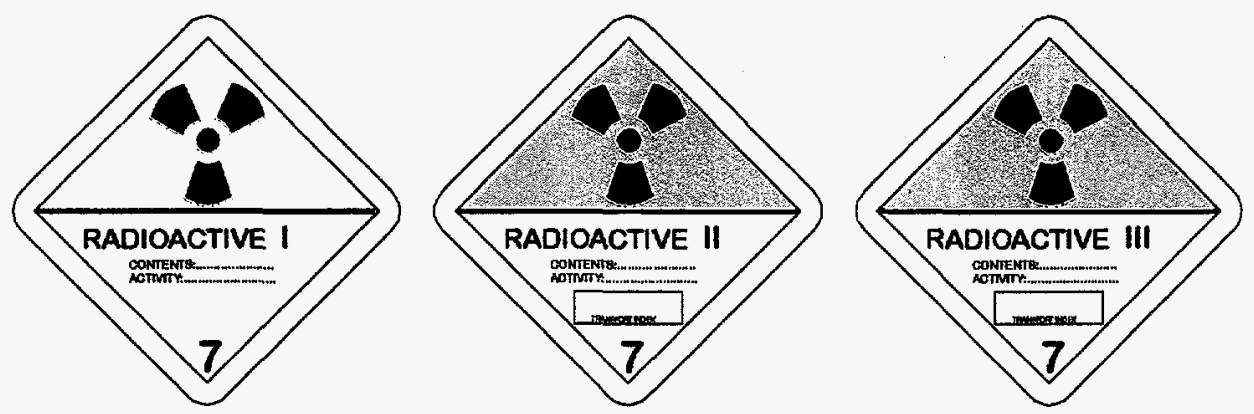

Figure 8. Package labels.

Vehicle placarding. When radioactive material packages bearing the radioactive-yellow-III labels are present on a vehicle, the vehicle must be placarded on the front, rear, and each side of the cargo-carrying part of the vehicle (i.e., the trailer), as well as on the front of the connected truck or tractor.

If a shipment is LSA and is shipped on an exclusive use vehicle, the individual packages are excepted from labeling, but the vehicle must be placarded. Unlike a non-exclusive use shipment, responsibility for placarding exclusive-use vehicles lies with the shipper.

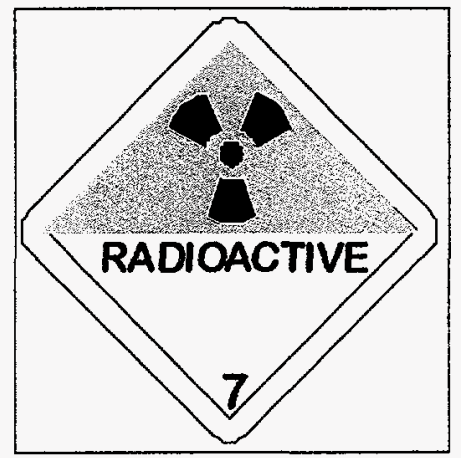

Advance notification of nuclear material or waste. Advance

notification is required if the activity (quantity) of the material or waste is equal to or greater than the DOT Highway Route Controlled Quantity (HRCQ), which is 3,000 times the $\mathrm{A}_{1}$ or $\mathrm{A}_{2}$ (as appropriate) or 27,000 $\mathrm{Ci}(1,000 \mathrm{Tbq})$, whichever is least. Advanced Notification requires:

1. Contacting the state governor or designee and regional NRC office

2. Notification of the state governor or designee when shipping to, through, or across state boundaries

3. Type B packaging

4. Following requirements of 10 CFR 73.37 (f) if carrying irradiated fuel

5. Notification by mail to the state governor or designee, postmarked at least 7 days before the beginning of the 7-day period during which shipment departure is expected.

6. Notification delivered by messenger reaching the office of the governor or of the governor's designee at least 4 days before the beginning of the 7-day period during which shipment departure expected. 
Emergency response. Emergency response regulations require the shipper to provide emergency response information on shipping papers, including the technical name of the material. This information must be made available at all locations where the material is handled during transport. The shipper must also provide an emergency response 24-hour telephone number. The phone number must be monitored at all times by a person who is either knowledgeable of the relevant emergency response information or has access to a person that does have the information. The regulations also allow that the telephone number may actually be that of an agent or other qualified person who is capable of and agrees to furnish the required information on a 24-hour basis. CHEMTREC, the Chemical Transportation Emergency Center, operated by the Chemical Manufacturer's Association, is an example.

Emergency response information requirements apply to any shipment of hazardous materials that is not excepted from shipping paper requirements.

Training requirements. $49 \mathrm{CFR} 172.700$ contain the requirements for training of employees ("hazmat employees") involved with the transpcrt of hazardous materials. This regulation requires that a employer ("hazmat employer") that handles hazardous materials must ensure that each of his/her hazmat employees receives the required training in the following subjects:

1. General awareness/familiarization (with $\mathbf{4 9} \mathbf{C F R}$ ). This requirement is intended to ensure that each employee is able to recognize and identify hazardous materials in a manner consistent with the hazard communisation standard of 49 CFR 172 . Successful training in this area will include a basic orientation on DOT shipping papers, package marking, package labeling, emergency response information and vehicle placarding requirements.

2. Function-specific training. This limits the training requirements to those hazardous materials activities actually involving the hazmat employee. Neither training nor testing is required for those hazmat activities not performed by the employer.

3. Safety training. After the initial required training (within 90 days of employment on a specific job), a hazmat employee must undergo recurrent training every two years or within 90 days after assignment to a new job for which training has not already been provided.

Driver requirements. Each driver of a commercial motor vehicle must be qualified for and have in possession a current Commercial Driver's License (CDL) with appropriate endorsements, in accordance with 49 CFR 383, "Commercial Driver's License Standards, Requirements and Penalties." The driver must be knowledgeable of the driver-related elements of 49 CFR 391 through 49 CFR 397 that contain the Federal Motor Carrier Safety Requirements. Pursuant to 49 CFR 397, any carrier or person operating a motor vehicle that contains regulated radioactive material for which placarding is required shall ensure that the motor vehicle is operated on routes that minimize radiological risk, considering available information on accident rates, transit time, population density, and activities along the route during the time and date of transit. A carrier or person operating a motor vehicle containing a HRCQ of radioactive material shall operate the vehicle only over "preferred routes." A preferred route is the interstate highway system or a state-designated alternate route selected by the qualified state agency. Pursuant to 49 CFR 397, the driver of a HRCQ vehicle must provide, or be provided by his employer, a written route plan and must have received specific training within two years prior to the shipment and must have in his possession during the shipment a certificate of such training.

Part 397 lists the rules for driving and parking when transporting radioactive materials. It is important to note that certain states may require stricter requirements. 


\section{Summary}

The process of answering the three questions noted at the beginning of this bulletin, (1) What are the characteristics of the radioactive material or waste that requires transport? (2) How can the radioactive material or waste be safely packaged?, and (3) How is the potential hazard of the material or waste being transported communicated to workers and the public? identifies the requirements and information necessary to ship radioactive materials and waste without incident. Strict adherence to the regulatory underpinnings of these three questions has resulted in an exemplary safety record for the transport of radioactive materials and waste.

\section{SAFETY IN THE TRANSPORTATION OF LOW-LEVEL RADIOACTIVE WASTE}

There are about $\mathbf{5 0 0}$ billion shipments of all kinds of commodities transported each year in the United States. About $\mathbf{1 0 0}$ million shipments transported are hazardous materials shipments. About 2 million or $2 \%$ of the hazardous materials shipments are radioactive materials shipments. ${ }^{8}$ Figure 9 shows a comparison of all shipments of all commodities per year to the number of hazardous and radioactive materials shipments per year. ${ }^{9}$

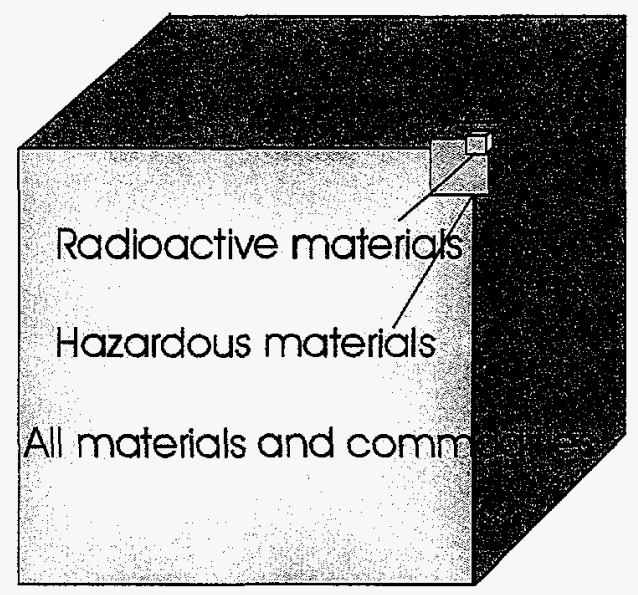

Figure 9. A comparison of all shipments of all commodities per year to the number of hazardous and radioactive materials shipments per year.

The Radioactive Material Incident Report (RMIR) ${ }^{10}$ database was used as the source for most of the information compiled in this section. This database, maintained by and accessed through Sandia National Laboratories, Albuquerque, New Mexico, contains information on transportation-related accidents

${ }^{8}$ J.D. McClure, H.R. Yoshimura, H.F. Fagan, and T. Thomas, Radioactive Material (RAM) Transportation Accident and Incident Experience in the U.S.A., SAND-97-2909C, Sandia National Laboratories, 1997.

${ }^{9}$ Murray, R.L., Understanding Radioactive Waste, 4th Edition, 1994.

${ }^{10}$ The Radioactive Material Incident Report data base contain transportation records for Low-level radioactive waste from 1971 through the present and can be accessed through TRANSNET. This data is available to the public. For more information about TRANSNET, call Sandia National Laboratories, (505) 845-8753. 
and incidents involving radioactive materials, including Low-level radioactive waste. The database, which covers the period from 1971 through the present, was developed to support DOE research and development efforts. The database was designed primarily to record information reported on DOT Form 5800 (Hazardous Materials Incident Report), used to document transportation incidents. Entries into the database meet both NRC and DOT rejgulatory requirements for incident notification. Three kinds of reported events are classified in the RIMIR and are defined as follows:

Transportation accident: Any accident that involves the vehicle transporting the radioactive material.

Handling accident:

Damage to a shipping container during loading, handling, or unloading operations (e.g., a forklift puncturing a package at an air terminal).

Reported incident:

Transportation occurrences where there is an actual or suspected release or surface contamination of radioactive materials that exceeds the regulatory requirements from either the package or the transport vehicle. (In the data base structure and query programs, a new category, Missing or Stolen, has been added to accommodate the request of other federal agencies using the RMIR data.)

During the past 25 years (1971-1996), 1,828 incidents involving radioactive materials were reported including transportation accidents, handling accidents, and reported incidents. By comparison, for the same period approximately 234,000 hazardous materials incident reports were made to the DOT. This means that of the hazardous materials incidents that were reported to DOT, radioactive transport incidents were approximately 0.8 percent $(1,823 / 234,000)$ of the reported incidents. ${ }^{8}$

During the past 25 years (1971-1996), 58 transportation accidents have involved approximately 1,100 packages of commercial Low-level radioactive waste. Of those 58 transportation accidents, only four involved the release of any Low-level radioactive waste (for example, a package opening). Out of a total of 48 packages in those 4 shipments, 22 were damaged severely enough to release some of the contents. (This amounts to $2 \%$ of the 1,100 packages involved in the 58 accidents). All of these packages were strong, tight packages and Type A packages, which are designed to withstand normal transport conditions, not accident conditions. Because of the limited quantity and concentration of the material released, however, the radiological harard was minimal in all cases.

No accidents involving Type 3 packages have resulted in a release of low-level radioactive waste. No injuries or deaths have been reported as resulting from the release of commercial Low-level radioactive waste during a transportation accident. Table 3 lists all the states that have experienced transportation accidents involving Low-level radioactive waste since 1971, along with the number of accidents in each of the states.

\section{Transportation Accidentsi Involving Commercial Low-Level Radioactive Waste}

There have been 58 transportation accidents involving Low-level radioactive waste in the last 25 years (as of 1996). Of these 58 accidents, 54 did not involve the release of Low-level radioactive waste. Following are brief descriptions of the four transportation accidents to date involving the release of commercial Low-level radioactive waste: 
- The first transportation accident on record involving a release of low-level radioactive waste occurred on January 12, 1976. A tractor-trailer en route to the Maxey Flats, Kentucky, disposal facility was traveling on I-64, 10 miles west of Catlettsburg, Kentucky, when it struck a Kentucky Bureau of Highways truck that was spreading salt on the icy roads. A total of 12 drums containing radioactive concrete and metal went through the trailer, hit the cab, and fell off the truck. Eight of the 12 drums ruptured when they hit the highway. Responders included Kentucky State Police, Department of Human Resources, and the Civil Defense Office. The radiation levels were not above normal background levels expected from natural radiation, so there was no radiological hazard. The released material was repackaged in new drums and sent to the disposal site.

- On November 22, 1987, a tractor-trailer was traveling on I-80 between Cheyenne and Laramie, Wyoming, with a shipment of radioactive hoses, metal parts, and radiumcontaminated soil en route from the Quadrex Recycle Center in Oak Ridge, Tennessee, to the Richland, Washington, disposal facility. A combination of driver error and weather resulted in the truck overturning. Five of the six metal boxes fell onto the road and median, emptying approximately one-third of the contents of each container. Responders included the Wyoming State Police, Wyoming Radiological Health Services, and the Department of Highways. The material was repackaged into 12 containers and sent back to the Quadrex Recycle Center in Oak Ridge, Tennessee. Personnel from the Wyoming Radiological Health Services conducted radiological surveys and determined that no radioactivity above normal background levels was present.

- On December 31,1987, a tractor-trailer en route to the Low-level radioactive waste disposal facility in Richland, Washington, was involved in a traffic collision and overturned on Stevens Drive in Richland. Five of the six metal boxes opened and released solid material onto the roadway. The responders included the Richland Police Department, the Department of Energy, Westinghouse, Richland Fire Department, Hanford Security, the Department of Social and Health Services (DSHS), and U.S. Ecology. The material was repackaged and sent to the disposal site. Personnel from U.S. Ecology, Westinghouse, and DSHS conducted radiological surveys and determined that no radioactivity above normal background levels was present.

- On October 24, 1989, a truck/flatbed trailer en route to the Barnwell, South Carolina, disposal facility was traveling on U.S. Hwy 460 in Christiansburg, Virginia, when the driver made a sharp left turn and the truck overturned. Four metal boxes with 384 cubic feet of soil containing uranium oxide fell off the truck and ruptured. The material covered a 25-squarefoot area. Responders included local fire and police departments and Virginia State Health Department personnel. The soil was repackaged and sent to the disposal site. Radiological surveys were conducted by responders and it was determined that no radioactivity above normal background levels was present.

\section{Transportation Accident Conclusions}

Only four transportation accidents have involved the release of commercial Low-level radioactive waste in the last 25 years. All the packages involved in the transportation accidents that released small quantities of material were strong, tight packages or Type A packages. Because of the limitations on radioactive material quantity and concentration imposed on these packages and because of the solid nature of Low-level radioactive waste, the radiological hazard to the public was minimal. No Type B packages have released Low-level radioactive waste in a transportation accident. There has never been a radiologically-related death or injury due to a transportation accident involving Low-level radioactive 
waste. The U.S. regulatory system, in addition to the training and efficiency of local authorities responding to the accidents and their prompt remedial actions, minimized any risk of exposure to the public or the environment.

Table 3. Transportation accidents involving commercial low-level radioactive waste, 1971-1996.

\begin{tabular}{|c|c|c|c|}
\hline & $\begin{array}{l}\text { Number of transportation } \\
\text { accidents involving } \\
\text { commercial low-level } \\
\text { radioactive waste }\end{array}$ & & $\begin{array}{l}\text { Number of transportation } \\
\text { accidents involving commercial } \\
\text { low-level radioactive waste }\end{array}$ \\
\hline States & radioactive waste & States & radioactive waste \\
\hline Arizona & 1 & North Dakota & 1 \\
\hline Colorado & 1 & Ohio & 2 \\
\hline Connecticut & 1 & Pennsylvania & 2 \\
\hline Georgia & 1 & South Carolina ${ }^{2}$ & 10 \\
\hline Idaho & 3 & Tennessee & 2 \\
\hline Illinois ${ }^{2}$ & 2 & Utah & 1 \\
\hline Iowa & 1 & Virginia & 2 \\
\hline Kentucky ${ }^{2}$ & 3 & Washington ${ }^{2}$ & 2 \\
\hline Missouri & 3 & West Virginia & 2 \\
\hline Montana & 5 & Wisconsin & 1 \\
\hline New Jersey & 1 & Wyoming & 2 \\
\hline New York ${ }^{a}$ & 5 & Washington, D.C. & 1 \\
\hline North Carolina & 2 & Oregon & 1 \\
\hline
\end{tabular}

a. These states are currently host states or are former host states to a commercial low-level radioactive waste disposal facility. 